\section{Dating mortars: three medieval Spanish architectures}

\section{Datando argamasas: tres ejemplos de arquitectura medieval hispana}

Juan Antonio Quirós Castillo

Universidad del País Vasco

Fabio Marzaioli, Carmine Lubritto*

Università di Napoli (Italia)

\begin{abstract}
One of the major issues in building archaeology is finding the age of elements and structures discovered. Mortars represent a class of material basically constituted by a mixture of different phases (i.e. binder, aggregates, water) and are widely used for constructive uses and artworks. Current scientific literature regarding the possibility of accurate radiocarbon dating for mortars reports different and still contradictory results. In this study, a new protocol for radiocarbon dating of mortar developed at the Centre for Isotopic Research on Cultural and Environmental heritage (CIRCE) is used to perform ${ }^{14} \mathrm{C}$ measurements on archaeological mortars coming from three medieval architectures of northern Spain (two churches and the walls of a castle). Results observed will be discussed and compared with independent age estimations (i.e. radiocarbon dating performed on organic materials found in the same study site, archaeological analyses) in order to frame experimental observations in the actual site knowledge by means of a multidisciplinary approach.
\end{abstract}

Key words: Mortar radiocarbon dates, historical architecture, stratigraphy, churches, walls.

\section{Resumen}

Una de las principales problemáticas a las que se enfrenta la arqueología de la arquitectura es datar los elementos y las estructuras. Las argamasas son un tipo de material constituido por una mezcla de diferentes elementos (agregados, agua) y empleadas en muchos tipos de construcciones. Los estudios realizados hasta la actualidad en torno a la posibilidad de realizar dataciones radiocarbónicas precisas han proporcionado resultados contradictorios.

El objetivo de este artículo es el de presentar un nuevo protocolo para datar la arquitectura histórica desarrollado por el Centre for Isotopic Research on Cultural and Enviromental Heritage (CIRCE), basado en la realización de dataciones radiocarbónicas de argamasas a partir del análisis de tres arquitecturas medievales del norte del España, dos iglesias y la muralla de un castillo. Los resultados obtenidos han sido confrontados y comparados con otros indicadores cronológicos independientes (dataciones radiocarbónicas realizadas en los mismos yacimientos, materiales y análisis arqueológicos) con el fin de analizar estos valores desde un enfoque multidisciplinar.

Palabras clave: Datación radiocarbónica de morteros, arquitectura histórica, estratigrafía, iglesias, murallas.

\footnotetext{
Respectivamente quiros.castillo@ehu.es Grupo de investigación en Patrimonio y Paisajes Culturales / Ondare eta Kultur Paisaietan Ikerketa Taldea de la Universidad del País Vasco, financiado por el Gobierno Vasco; fabio.marzaioli@ unina2.it y carmine.lubritto@unina2.it Dipartimento Scienze Ambientali, Laboratorio CIRCE, II Università di Napoli.
}

\section{INTRODUCTION}

One of the major issues in building archaeology is to determinate the absolute age of architectural elements and structures discovered during the works. Unfortunately we are not always faced with buildings constructed with items that may be analyzed by using typological or stylistic methods that give us some indications concerning the period of their implementation, and therefore, it is necessary to use different methodologies. In fact, to determine the age of buildings, building archaeology has adopted, in recent years, a large volume of analytical tools (Mannoni 1984). In other words, in the absence of instrumental methods to determine absolute age, the only option is to rely on historical dates and archaeological markers, which often require the presence of artefacts to be used as «guide fossils» (Hale et al., 2003). Mortar represents a class of material basically constituted by a mixture of different materials (i.e. binder, aggregates, water) and widely used for constructive uses and artworks. Because of their productive process, mortars preserve the potential to be used for radiocarbon dating and since 1964 (Delibrias \& Labeyrie, 1964) several scientists have tested this hypothesis without a clear understanding of the accuracy achievable in the artifact dating.

The opportunity to apply the ${ }^{14} \mathrm{C}$ dating tool to mortars constitutes a possible breakthrough point in the actual knowledge because:

1. mortars represent a class of materials widespread on the archaeological excavations;

2. dating mortars, in principle, represents an unbiased chronological anchor for the study of buildings and other structures previously dated indirectly by means of organic materials found, when present, in the context of the study site.

Lime mortars preserve the potential to define the absolute chronology of a studied artifact by means of radiocarbon $\left({ }^{14} \mathrm{C}\right)$ because only during their hardening, happening on timescales negligible with respect to ${ }^{14} \mathrm{C}$ half life, they absorb large aliquots of atmospheric $\mathrm{CO}_{2}$ recording the time of building up of a given artifact (Van Strydonck et al., 1986) in an anthropogenic (secondary) carbonate buffer.

Mortar production process can be resumed in four steps (Fig. 1).

1. Burning of a carbonatic limestone at $\mathrm{T}-900^{\circ} \mathrm{C}$ in traditional limekilns (calcination)

$$
\mathrm{CaCO}_{3} \rightarrow \mathrm{CaO}+\mathrm{CO}_{2} \text {. }
$$


Calcination process removes $\mathrm{CO}_{2}$ of fossil origin from the initial (primary) carbonate producing quicklime virtually free of $\mathrm{C}$;

2. Watering of quicklime then undergoing hydration and producing slaked lime

$$
\mathrm{CaO}+\mathrm{H}_{2} \mathrm{O} \rightarrow \mathrm{Ca}(\mathrm{OH})_{2}
$$

$\mathrm{Ca}(\mathrm{OH})_{2}$ crystals (portlandite) are aged under water excess in the form of lime putty. During this period portlandite crystals are rearranged, becoming smaller and foil like enhancing their future $\mathrm{CO}_{2}$ absorption capability;

3. Mixing of aged lime putty with aggregates (e.g. reworked bricks, silica minerals,...) to increase workability, hydration and avoid cracks due to drying during setting;

4. Slaked lime absorbs $\mathrm{CO}_{2}$ from air (carbonation) over time periods of few years

$$
\mathrm{Ca}(\mathrm{OH})_{2}+\mathrm{CO}_{2} \rightarrow \mathrm{CaCO}_{3}+\mathrm{H}_{2} \mathrm{O}
$$

forming a secondary anthropogenic carbonate.

If the burning of the primary carbonate is efficient, $\mathrm{C}$ composing mortars is ascribable only to atmospheric $\mathrm{CO}_{2}$ (unique $\mathrm{C}$ end member hypothesis).

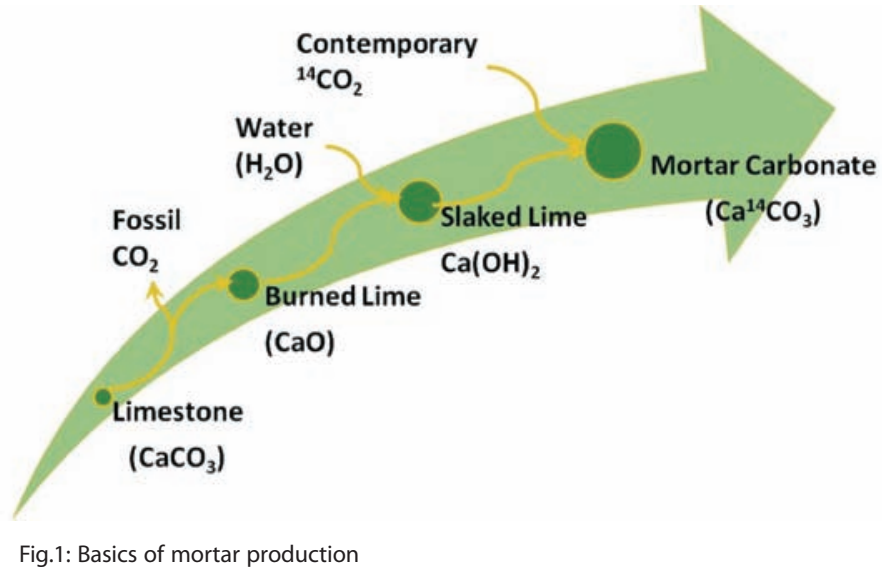

Since the 1960's radiocarbon community began investigating the potential of mortars to serve as a chronometer for the determination of the ages of structures (Delibrias \& Labeyrie, 1964, Folk \& Valastro, 1976, Van Strydonck et al., 1986, Heineimer et al., 1997, Sonninen \& Junger, 2001).

Other studies tried mortars indirect dating by analysing charcoals found in the mortars (Gallo et al., 2000). However, they can represent only a lower limit to the age estimation of mortars as they can at best be attributed to the wood used to cooke the primary carbonate in the lime kiln and they are usually older.

Current scientific literature regarding the possibility of radiocarbon dating mortar reports different results with still contradictory results. To date, over about 50 years of experimentations observed variability of the radiocarbon results lead to a still unclear methodology to prosecute with the aim of repeatable accurate dating. Most of the observed inaccuracy of the dating method often derives from the presence of carbonaceous residuals of limestone, drastically increasing the mortar age estimation contributing with significant aliquots of dead carbon. Also the usage of carbonate sands can add significant aliquots of dead C.

Scientific evidence indicate how most of these uncertainties are attributable to the lime mortar production and environmental exposure processes:

1. limestone carbonate residues (calcination relics) which may take origin from the incomplete baking of the limestone (primary carbonate) during the quicklime $(\mathrm{CaO})$ production add a dead $\mathrm{C}$ $\left({ }^{14} \mathrm{C}\right.$ free $)$ carbonate fraction leading to age overestimations;

2. calcareous sand which adds an ageing effect similar to the dead $\mathrm{C}$ residue of the primary carbonate;

3. aggregates, any type of material, from reworked bricks and marble to stone waste;

4. running water containing dissolved $\mathrm{CO}_{2}$ can cause a supplementary deposit (ternary carbonates) on the mortar or an exchange in carbonate ions. This effect is not evaluable in advance since the effect of ternary deposits, when evaluable (i.e. long exposition times) can result in either an ageing (e.g. water table submersion) or a rejuvenation (e.g. rain dissolved inorganic C (DIC)) effect.

Most of the existing methodologies aim to isolate binder from other materials, preserving a trace of the ${ }^{14} \mathrm{C}$ signature of the atmosphere absorbed during mortar setting.

While contaminant sources described in points 2 to 4 can be suppressed by means of different kind of procedures regarding the choice of the most appropriate sample (i.e. not directly exposed to the environment but not completely screened by the $\mathrm{CO} 2$ interaction) and the exclusion of aggregates as efficient as possible, primary carbonate dead C contamination (point 1) is the most relevant source of bias of aerial mortars (Van Strydonck et al., 1986). Sampling of mortars not directly exposed to watering can only avoid the rejuvenation effect while, in the case of 
water table submersion, the DIC biasing effect can not be easily removed. If the proposed methodology has not been tested yet on the suppression of this last effect, in these cases the knowledge of the hydrogeology of the excavations represents the best sample discriminator.

In this study, a new protocol for radiocarbon dating of mortar developed at the Centre for Isotopic Research on Cultural and Environmental heritage (CIRCE) is presented (Marzaioli et al. 2011). This innovative procedure is based on the isolation of the binder carbonates from a series of mortars. These fractions are then used to perform ${ }^{14} \mathrm{C}$ dates on archaeological mortars coming from three medieval architectures of northern Spain (two churches and the walls of a castle). Results obtained will be discussed and compared with independently estimated chronologies (i.e. radiocarbon dating performed on organic materials found in the same study site, archaeological analysis) in order to give an interpretation of results with a multidisciplinary approach.

\section{MATERIAL AND METHODS}

\subsection{Laboratory isolation procedure}

As discussed above, the opportunity offered by the carbonation process (atmospheric $\mathrm{CO} 2$ adsorption) leading to the hardening of the mortars during their usage for constructive or artistic usages has been widely tested by the radiocarbon community aiming to evaluate absolute chronology of artifacts avoiding the usage of non direct age estimation/measurements. The presence of unburned primary limestone, survived to the mortar production technology, was found to be one of the main reasons responsible for drastically altering the radiocarbon age of mortars by introducing big aliquots of dead C. In this paper we use a new protocol, based on the isolation of a suspension of carbonaceous materials by means of strong ultrasonic attacks, able to ensure an efficient suppression of dead C contamination for simplified mortars, produced according to conventionally used temperatures $\left(800-1100^{\circ} \mathrm{C}\right)$.

The procedure is based on the following steps (Fig. 2):

1. Mortar cryobraking;

2. Sieved $(500 \mathrm{~mm})$ fragments ultrasonication;

3. Suspension centrifugation;

4. Overnight drying;

5. Acid digestion and isotopic measurements on isolated suspensions.

Our protocol is based on a modification of the procedure described by Nawrocka et al. (2005), and is based on the assumption that binder carbonates are characterized by an easily breakable structure (i.e. by means of strong ultrasonication attacks). Mortar samples were broken by a series of freezing/thawing cycles. Bulk mortars (5$10 \mathrm{~g})$ were submerged in liquid nitrogen for about 5 minutes and rapidly moved into an oven at $80^{\circ} \mathrm{C}$. After at least 3 cycles, raw materials were crushed by means of gentle hammering. The operator using a 20x stereoscope performed gross selection manually and, subsequently,

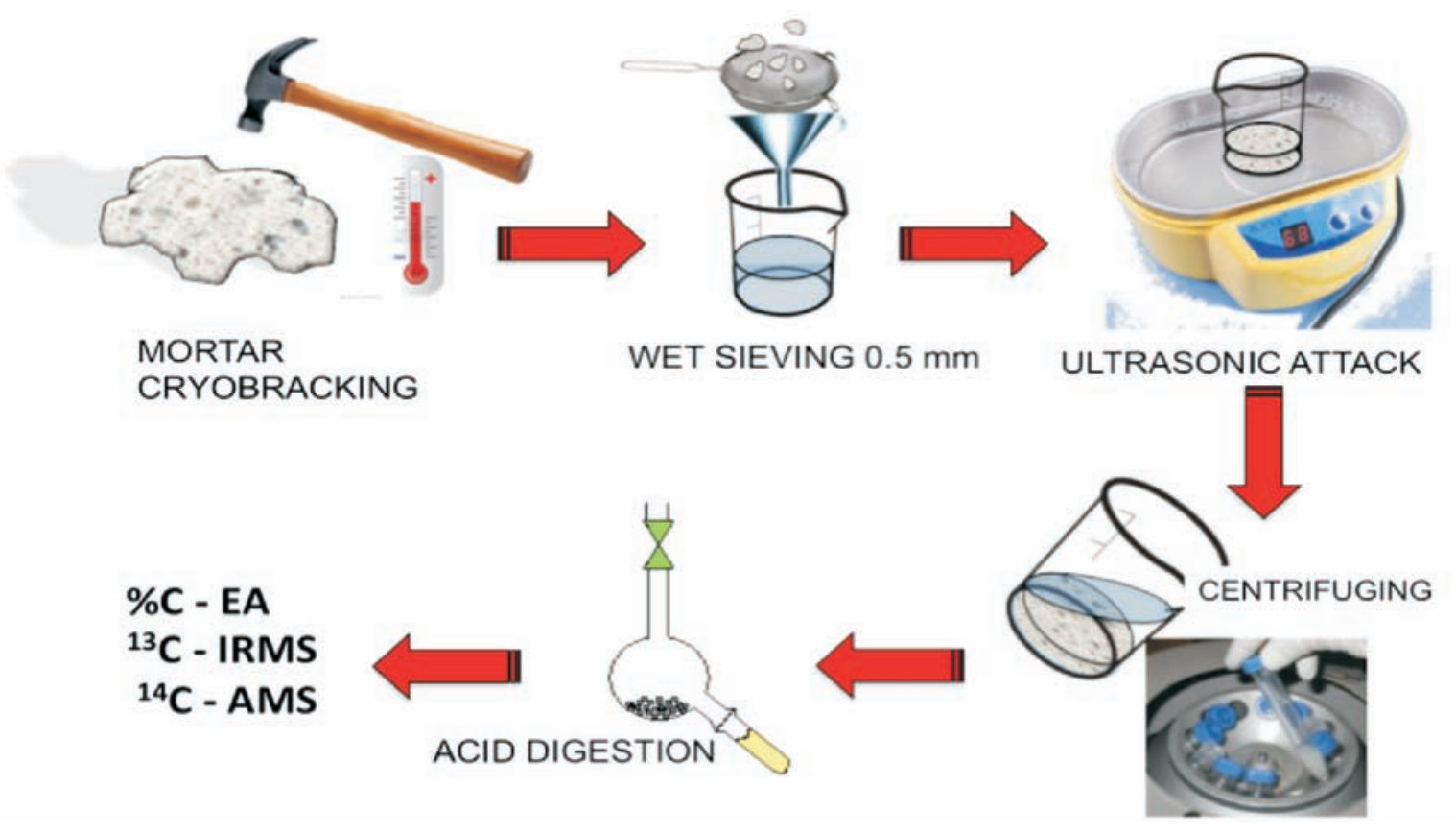

Fig.2: New protocol for mortar preparation 
finer particles were isolated by a sieving $(0.5 \mathrm{~mm})$. The residue of this selective procedure, mostly the binder and the calcination relics, underwent ultrasonication in an excess of deionized/decarbonicated water for 45 minutes in a beaker. In our opinion this step is supposed to separate the binder signal isolation from the carbonate lumps by breaking the binder minerals originating in a suspension of carbonates characterized by a slower sedimentation velocity $\left(\mathrm{v}_{\mathrm{s}}\right)$ because of their smaller average diameter $\left(\mathrm{d}_{\mathrm{p}}\right)$. The liquid phase of the produced suspension was gently siphoned in $50 \mathrm{ml}$ Falcon centrifuge tubes and centrifuged for 5 minutes at $8.5 \mathrm{krpm}$ to separate the suspension from the water medium. The water filling the tubes was gently removed and the fraction of interest (suspension) was dried overnight in an oven at $70^{\circ} \mathrm{C}$.

Protocol isolated suspensions underwent ${ }^{14} \mathrm{C}$ analyses, performed by means of a complete orthophosphoric acid $\left(\mathrm{H}_{3} \mathrm{PO}_{4}\right)$ attack. Ampoules for isotope analyses containing the carbonate materials $(20$ to $110 \mathrm{mg}$ ) and a frozen excess of $85 \% \mathrm{H}_{3} \mathrm{PO}_{4}$ were evacuated $\left(<10^{-3} \mathrm{mbar}\right)$ and detached from the line after isolation. $\mathrm{H}_{3} \mathrm{PO}_{4}$ digestion was developed in an oven $\left(85^{\circ} \mathrm{C}\right)$ for a period of 2 hours. Produced gasses underwent cryogenic purification by means of a vacuum line to separate evolved $\mathrm{CO}_{2}$, used for the radiocarbon sample pretreatment/measurements.

Radiocarbon analyses were performed on the graphite developed from the digested $\mathrm{CO}_{2}$ following the zinc reduction process (Marzaioli et al., 2008). In the aim to check for the entire procedure accuracy, reproducibility and induced background, IAEA C1 (background), IAEA C2 (normalization) and several check standards were prepared following the same procedure. Graphite samples were measured by means of the CIRCE-AMS system for the measurement of radiocarbon isotopic ratios (Terrasi et al., 2008). For the purposes of this study we present ${ }^{14} \mathrm{C}$ data, according to Stuiver \& Pollach (1977), in both pMC (percent of modern carbon), mostly used for geochemical scopes and to express post '50s ages, and radiocarbon (R.C.) age.

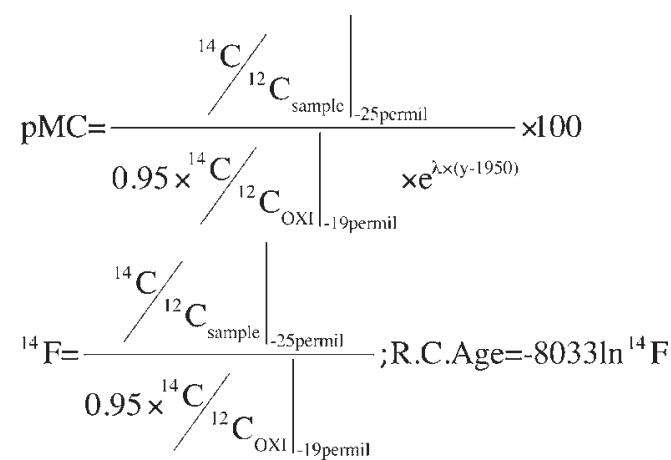

In both definitions measured isotopic ratios of the sample and the primary standard (OXI) are corrected for isotopic fractionation to a $\mathrm{d}^{13} \mathrm{C}$ value of -25 and $-19 \%$ respectively. Moreover, in the pMC notation the OXI isotopic ratio is scaled for decay to 1950 . In this study some ${ }^{14} \mathrm{C}$ measurements are converted in R.C. ages and, via calibration, in calendar ages and expressed in A.D. years, reporting B.C. dates as negative A.D. values. Calibration of radiocarbon ages was performed by means of OxCal software. All these dates are reported by means of the probability-weighted averages of the medians of the calibrated ranges, while error bars represent $1 \mathrm{~s}$ and $2 \mathrm{~s}$ maximum and minimum ranges.

\subsection{Study Sites}

To assess the potential of this methodology, radiocarbon dating campaigns were conducted on three mortars sampled from medieval buildings located in the provinces of Alava and Burgos - Spain (Fig. 3), which have already been studied during several archaeological projects in recent years.

In particular we have studied two churches, Santa Maria in Zornoztegi and San Julian in Aistra, and the walls

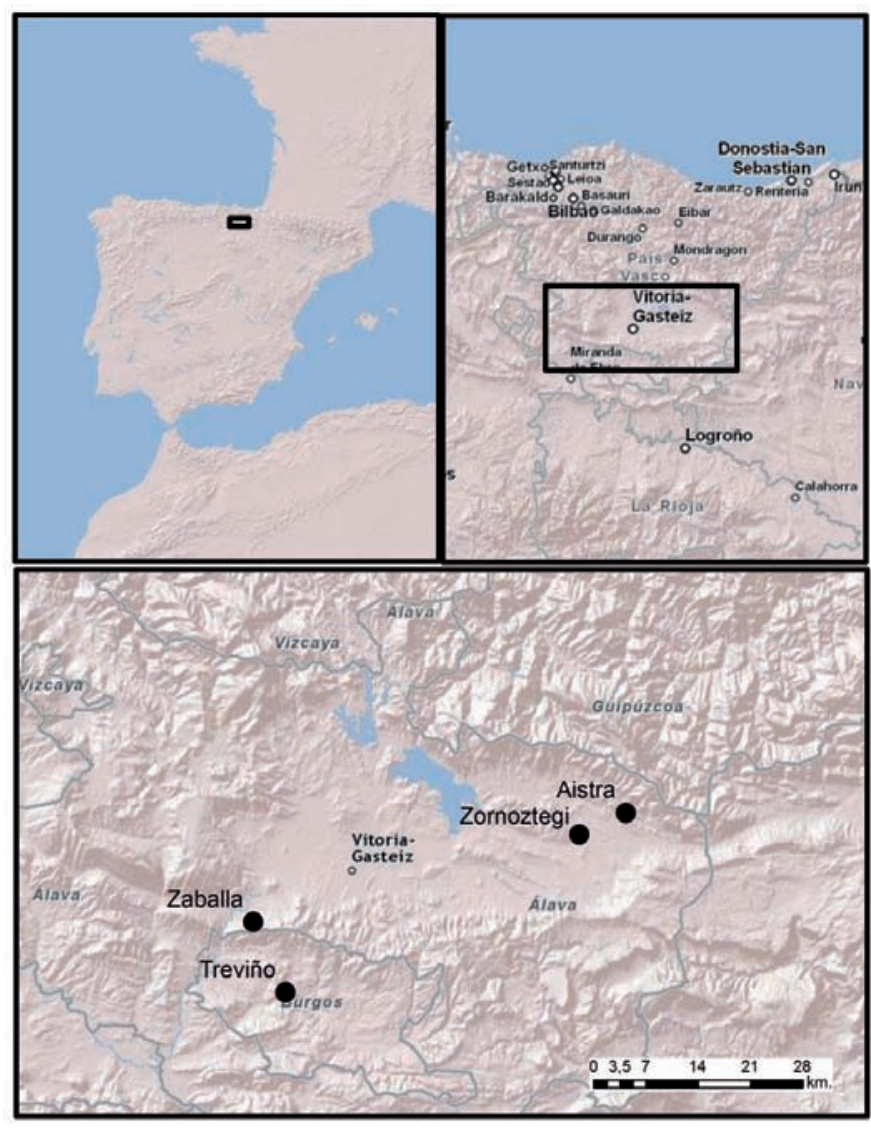

Fig. 3. Map with the localization of the three analyzed sites in the text 
of the castle of Treviño. The first church chronology is well-constrained in the first half of the $12^{\text {th }}$ century, the second church was dated in a range of time between the end of the $9^{\text {th }}$ century and the $10^{\text {th }}$ century, while the chronology of the walls of Treviño castle is almost unknown. In the following sections, details concerning each archaeological site are given.

\subsubsection{Santa Maria Church, Zornoztegi (Alava)}

The village of Zornoztegi is in the east of the province of Alava, in the municipality of Salvatierra. This archeological site, deeply studied in the 2005-2009 period, developed continuously in the period ranging from the $5^{\text {th }}$ to the $14^{\text {th }}$ century with a first settlement during the Bronze Age (Quirós Castillo 2010).

During the excavation, in the Northern sector of the site a small parish church was found, not visible on the surface because it had been destroyed and plundered during the modern age (Fig. 4). The village was deserted before 1468; in fact, a document from 1520 describes the church as 'la hermita cayda que dizen de çornoztegui'. It is very likely that after this date, the stone of the church was sold, as has happened with other deserted village churches in Alava. In any case, the excavation has recovered the foundations of the nave and the foundation trench of the apse.

The church was built on top of a previous building (E6) with a domestic function, consisting of two semiexcavated cuts on the natural and some postholes. Over the occupation levels of this dwelling, a constructive level has been found arranged to build the church, made from domestic waste from the previous occupation. The pottery from these deposits was dated between the $11^{\text {th }}-12^{\text {th }}$ centuries, date that was confirmed and limited to the first half of the $12^{\text {th }}$ century by using the radiocarbon date from a small piece of charcoal (quercus) recovered by the flotation of this constructive level (context 1235) and various bone samples. Moreover, it should be pointed out

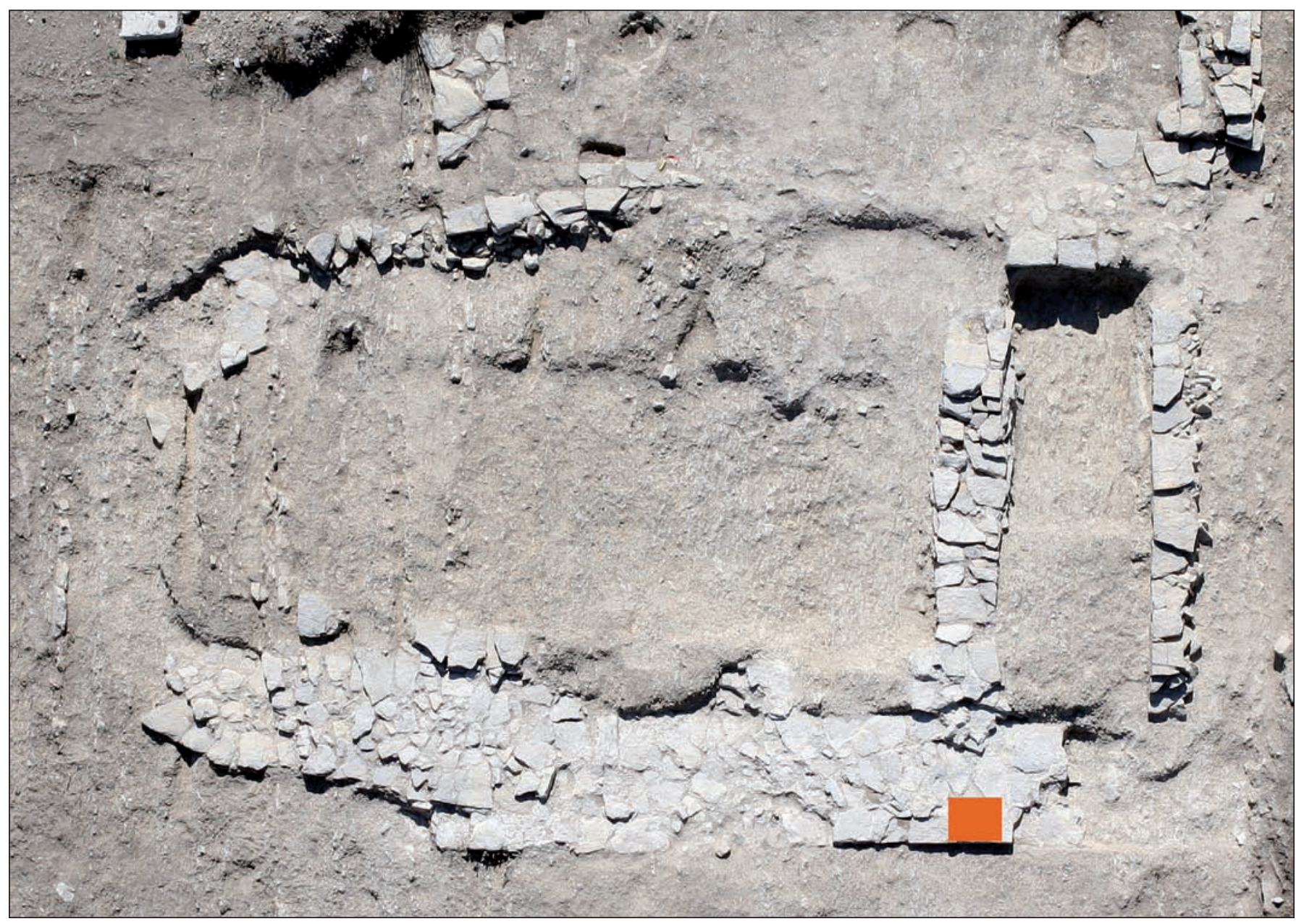

Fig. 4. Santa Maria of Zornoztegi church (Salvatierra, Agurain, Alava) in which has been indicated the sample area 
that the use of the semicircular apse and the characteristic constructive techniques shown in the ashlars of the foundation reinforce the date of the building to the first half of the $12^{\text {th }}$ century.

Therefore we can say that the archaeological record allowed us to date quite precisely the construction of Zornoztegi's parish church of Santa Maria and than in order to calibrate our mortar dating protocol, a mortar sample was collected from this site. To avoid weather exposure contaminations, one sample that was not on the surface of a wall of this structure was sampled and analyzed (context 1106 - lab code ZOR07).

\subsubsection{San Julian and Santa Basilisa Church, Aistra (Alava)}

The second site studied is the early medieval church of San Julian and Santa Basilisa, in Zalduondo, a small church made with large sandstone ashlars, regular and well carved, being one of the oldest medieval buildings still preserved nowadays in Alava (Fig. 5). It is a rectangular building articulated into three sections: a rectangular apse, from which a window stands out with an ultra semicircular arch, used as a stylistic element to date the building (Fig. 6); the rectangular nave; and a later extension to the west made at the end of the $18^{\text {th }}$ century (García Retes 1985,454 ).

The chronology of this structure is mostly based on formal and stylistic analyses of windows and walls, and is still contradictory. In $1970 \mathrm{~A}$. Suarez Alba fixed the date of the church in the Visigoth period and J. Fontaine (1978, 465) also recognized Visigoths items in the walls, although he did not specify an accurate date. Other authors have dated since $11^{\text {th }}$ century (Catón, Guinea García 1987, 30) or have ascribed it to the Mozarabic period (Azkarate 1988, 120), while A. Arbeiter (Arbeiter et al., 1994) has ascribed the fabric to the $10^{\text {th }}$ century, whereas A. Azkarate and L. Sánchez have dated construction of the church in the $9^{\text {th }}$ century (Azkarate, Sánchez 2003, 31).

Later on Sánchez (Sánchez Zufiaurre 2007, 108-117) made a detailed stratigraphic analysis of the building, recognizing the existence of a first 'prerromanesque' phase from the 'romanesque' reforms of the apse and the nave. The chronology of this first phase was obtained starting from the previous studies performed by I. García Camino on other Biscayan buildings with similar windows (García Camino 2002, 180-181), that placed these buildings among the end of the $9^{\text {th }}$ century and the mid of the $10^{\text {th }}$ century. This interpretation was confirmed by similar stratigraphic reading suggested by M. A. Utrero (2006, 595).

Between 2006 and 2009 a new archaeological project was done in collaboration with Andrew Reynolds (Institute of Archaeology, University College of London), based on the extensive excavation of the whole archaeological site. The main aim was to study the building in context, in order to further refine its chronology within the framework of an entire Aistra deserted village and discover the presence of features associated with the church.

The archaeological results have shown that the area was occupied during the whole Early Middle Ages and that since the $7^{\text {th }}$ century it was an important centre. Besides, it

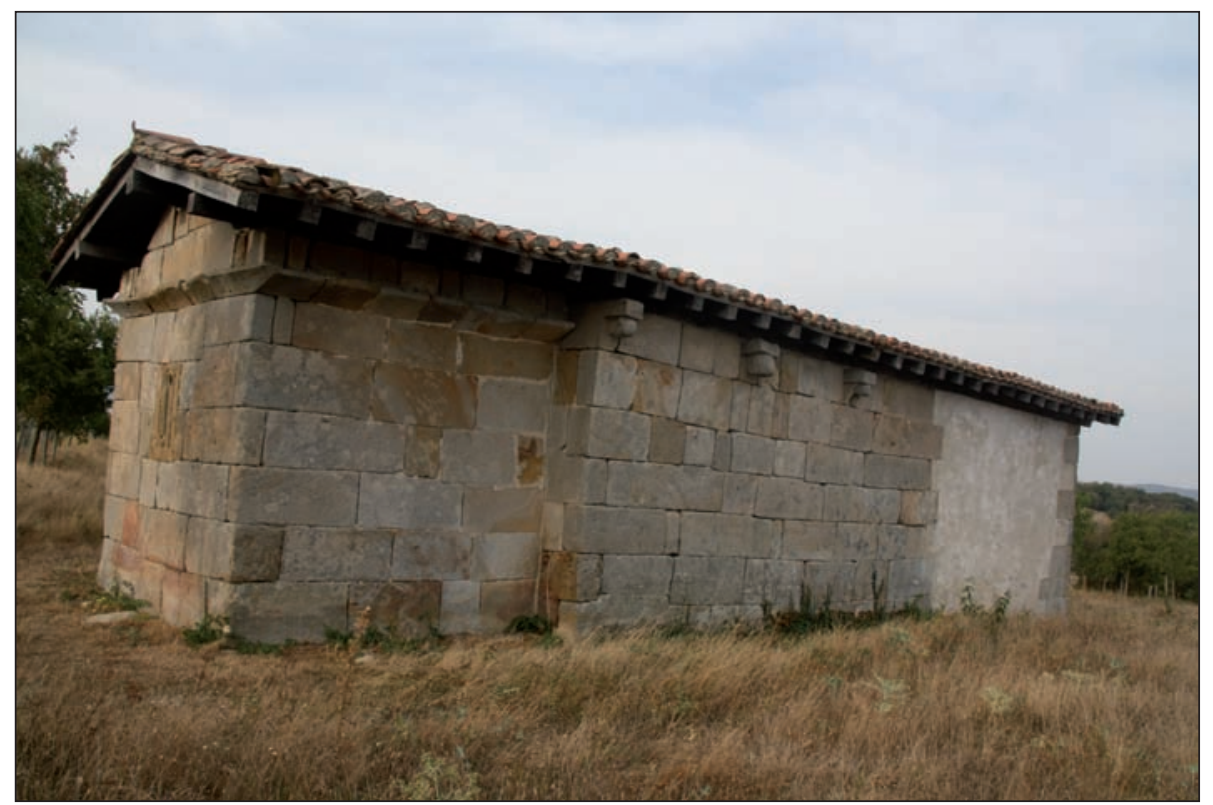

Fig. 5. San Julian and Santa Basilisa church di Aistra (Zalduondo, Alava) 


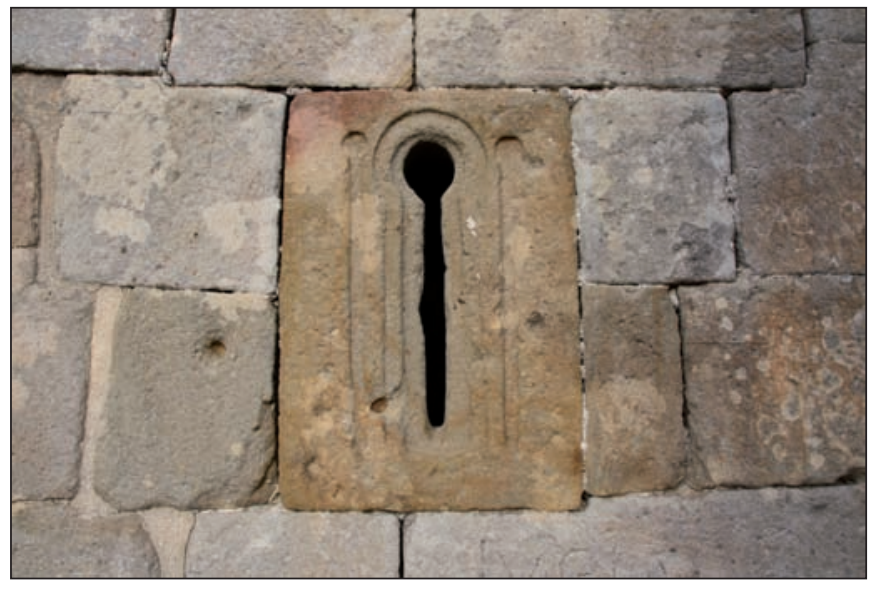

Fig. 6. Apse window of San Julian and Santa Basilisa church (Aistra, Zalduondo, Alava)

was possible to determine that the church of San Julian, together with some adjoining tombs, could be chronologically fixed into the fourth phase of the site. The archaeo-

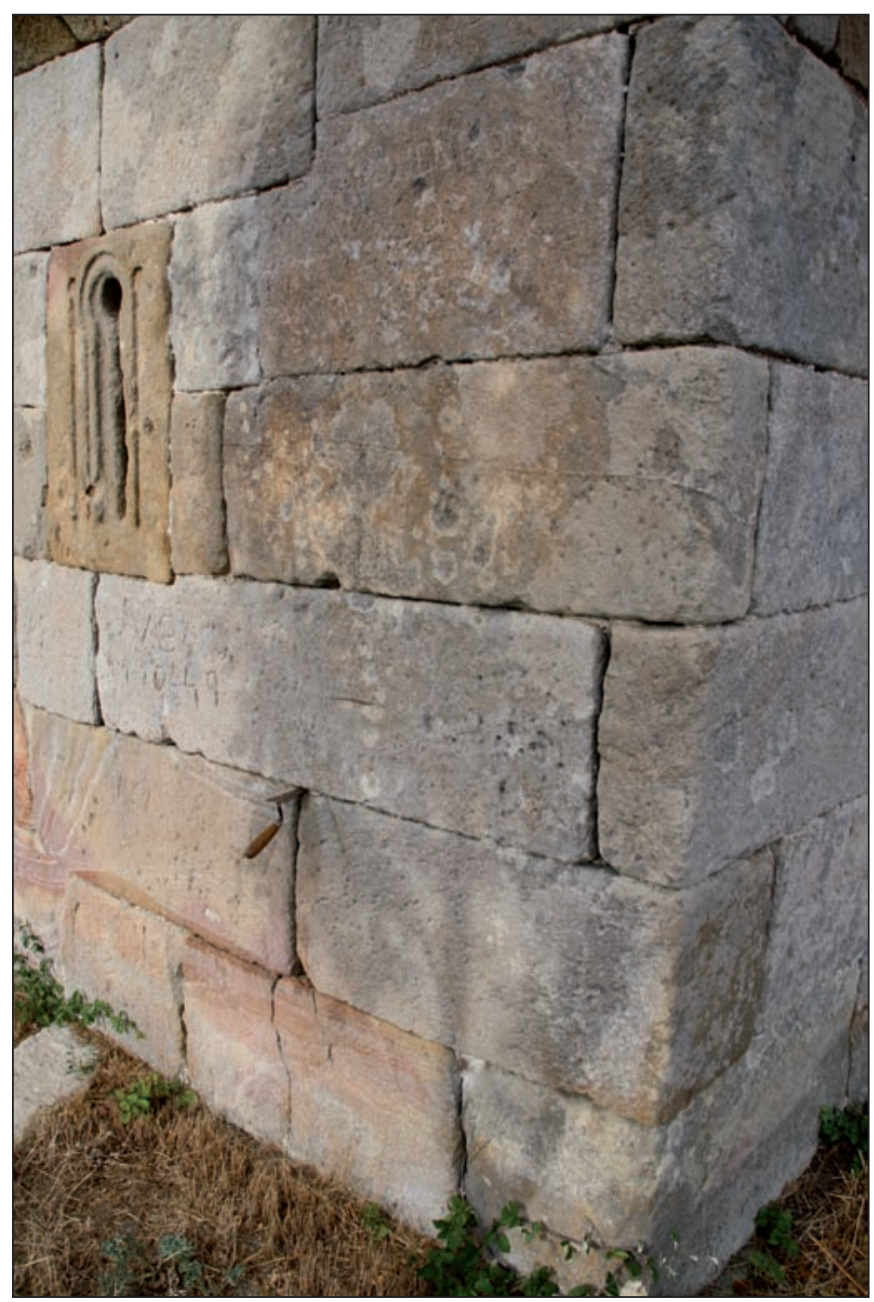

Fig. 7a. Sample AISTRA 1 logical dating of the church has caused many problems because we did not get stratigraphic elements or new materials that allowed us to tune the proposals made with stylistic or typological terms. During the restoration of the building in the early 80 's, the inside of the church was completely excavated, but there were no useful elements to date. The perimeter was excavated as well, which involved the difficulty of relating the stratigraphic sequence with the building itself. At the same time the cemetery located around the church was also excavated, although it did not give useful chronological elements. Only one tomb situated in the exterior of the apse in its central axis, provided a reused funerary stele and was ascribed to the $10^{\text {th }}$ century (Azkarate, García Camino 1996, 139-140).

Taking into account the above, two mortar samples have been taken from the walls of San Julian church following the stratigraphic reading.

In the archaeological project, it has been possible to review the entire sequence created by L. Sánchez or M. A.

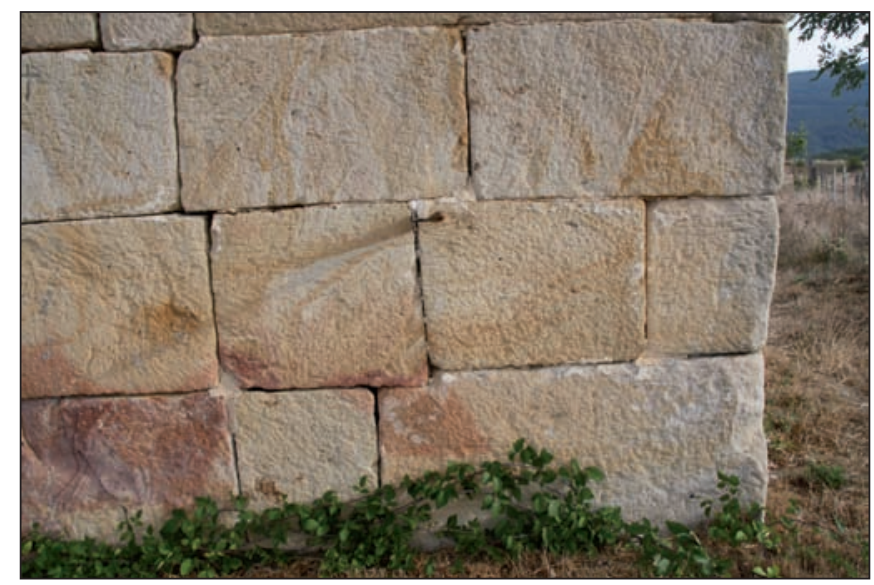

Fig. 7b. Sample AISTRA 2

Utrero and confirm that the oldest walls are the ones on the north-eastern corner of the apse, where the window lies and the nave extends, whereas the rest of the walls from the apse are more recent. Therefore, the sampling was performed in order to chronologically check both the first phase (sample called AISTRA 1) followed by the second phase (sample AISTRA 2).

\subsubsection{Treviño Castle (Burgos)}

Treviño, a small town actually accounting for about 200 inhabitants, is the capital of a wide municipality with fifty villages belonging to the province of Burgos, an enclave inside the province of Alava. The place is characterized by an intense historical pathway beginning in the $10^{\text {th }}$ century 


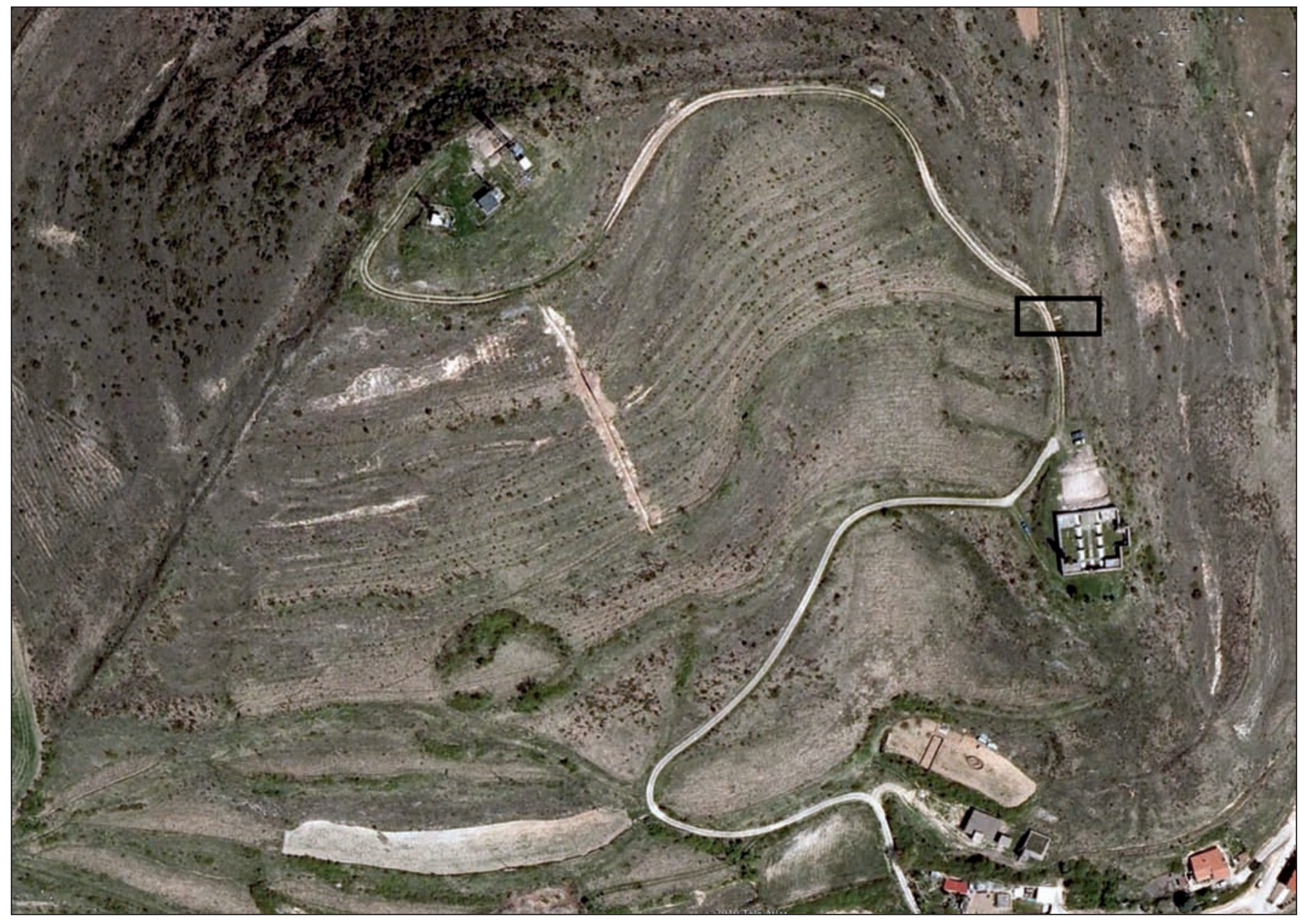

Fig. 8. Aerial photography of the Treviño site (Condado de Treviño, Burgos) in which have been indicated the sample areas

and leading to it becoming the capital of the Condado de Treviño during the $15^{\text {th }}$ century. The town, which is nowadays a modest rural center, is located at the bottom of a hill that is still known as «El Castillo» (Fig. 8).

On this hill, large amounts of archaeological remains have been found, such as a deep moat, a medieval church from the $12^{\text {th }}$ century devoted to Santa Maria, nowadays cemetery of Treviño, and a wall which, from the top of the hill, comes down to the town, defining a wide walled perimeter.

Since 2008, an in-depth investigative archaeological project was performed with the aim of unravelling the story of the site before it became a part of the kingdom of Navarra around the $12^{\text {th }}$ century. This is why several trenches and excavations have been dug in different sectors of the site, allowing us to define an interesting occupation sequence (Quirós Castillo 2011).

The hill was occupied during the second Iron Age, and after a long hiatus, was re-occupied from the $10^{\text {th }}$ century onwards. The archaeological deposits from the $10^{\text {th }}-12^{\text {th }}$ centuries tell us that during this period it was a manorial castle articulated into several areas with different functions. At the top of the hill, a manorial building has been uncovered, with large silos used for the income by peasants. Between the hilltop and the current town you can find the church of Santa Maria and close by there is a flat sector with peasant houses, which shows the existence of a concentration of the peasant settlement inside the fortified area.

Moreover, in the inner part of the current town, an occupation dated between the $11^{\text {th }}-12^{\text {th }}$ centuries has been identified, which confirms that the settlements were not all inside the walled area, but at least, in the $11^{\text {th }}$ century, there were more settlement areas.

Therefore, one can think that this is an incastellamento process in the classic sense, where the complete concentration of the settlement did not take place. In any case, there has been a deep transformation of the manorial character 


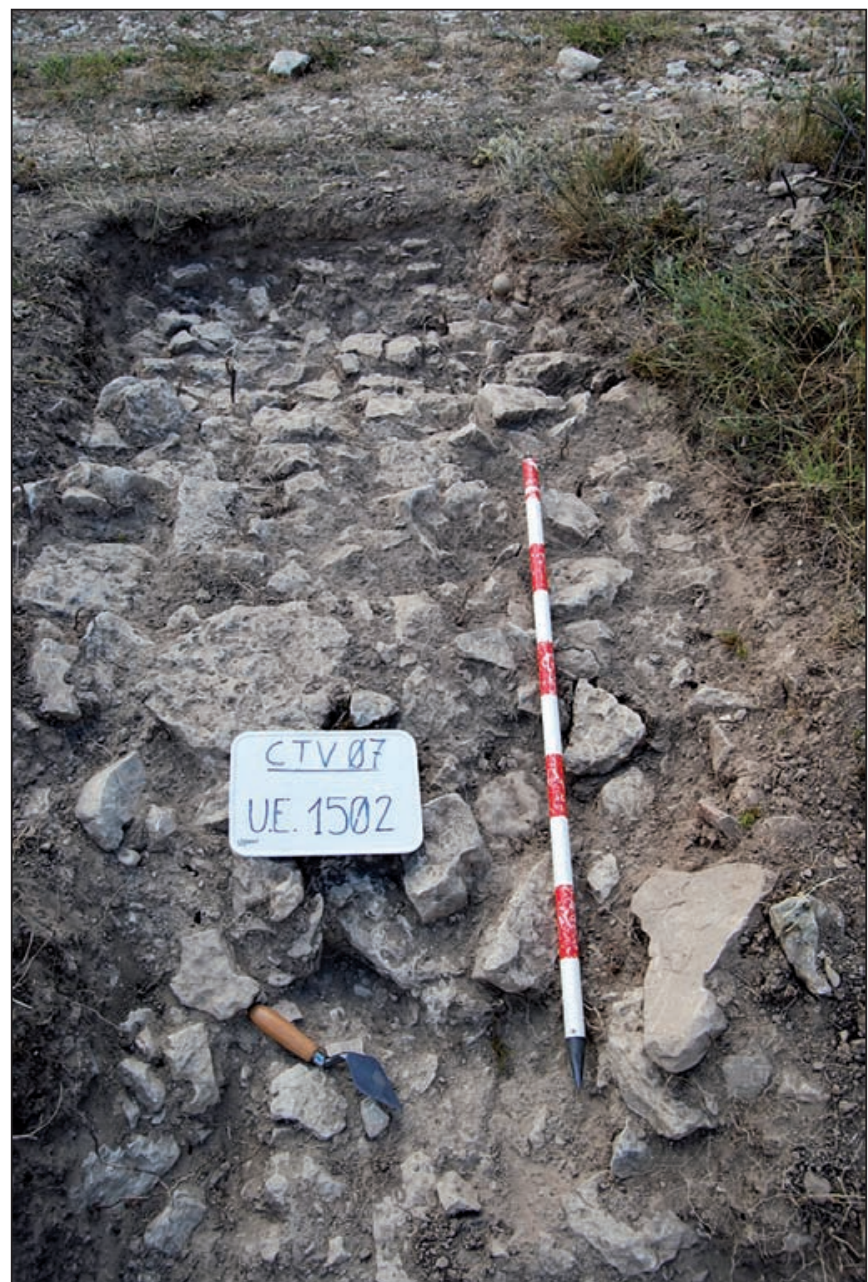

Fig. 9. Wall stretch of the Treviño castle in which the radiocarbon dating has been made

of the inhabited area, keeping in mind that the formation of the village systems had begun in this area much earlier than the $10^{\text {th }}$ century. From the $13^{\text {th }}$ century on, the population was located at the bottom of the hill, with the consequent desertion of the peasant neighbourhood of the castle, and the division between a manorial area in the hilltop and the town at the bottom.

With this framework, other objectives of the archaeological project have been to analyse the materiality of the castle in the first centuries of Treviño, as well as define its dimensions and characteristics.

The studies of the trenches and excavations allowed us to verify the existence of a continuous occupation from the $10^{\text {th }}$ century in the hilltop and in the sector near the church. At the same time, it was not possible to spatially relate both sectors and determine if they were part of only one period of occupation or the peasant neighbourhood was simply located near the castle.
To solve this spatial morphology, the wall that descends from the castle to the church was analysed. For this reason some trenches were made in its course, in order to analyse the constructive technique and observe that it had been intensely plundered over time. Unfortunately no useful elements concerning its chronology were found. Therefore a mortar sample from one of the devastation surfaces of the wall (sample context 1502) has been taken. (Fig. 9).

Two could be the interpretative settings: the wall had been made in an early moment of the castle occupation, implying the incastellamento process; or that it had been made later in the framework of the royal town. More precisely, in a document dated 1254 the King Alfonso X of Castile grants a series of privileges to Treviño, and demands that the local council builds a moat and a towered wall to protect the town.

\section{RESULTS AND ARCHAEOLOGICAL ANALYSIS}

\subsection{Santa Maria Church - Zornoztegi}

For the sample coming from this site, radiocarbon dating result is 1019-1148 AD (1 $\sigma)$ (Fig. 10, 11) and it is completely coherent with previous archaeological interpretation because it confirms a chronology of the church between $11^{\text {th }}$ century and first half of $12^{\text {th }}$ century.

\begin{tabular}{|c|c|c|c|c|}
\hline Sample Name & Radiocabon age & error & Calibrated age l & Calibrated age 2 \\
\hline $\begin{array}{c}\text { ZOR07 } \\
\text { UE1106 }\end{array}$ & 978 & 40 & $1019-1148 \mathrm{AD}$ & $989-1159 \mathrm{AD}$ \\
\hline $\begin{array}{c}\text { CTV07 } \\
\text { UE1502 }\end{array}$ & 1184 & 57 & $773-941 \mathrm{AD}$ & $681-987 \mathrm{AD}$ \\
\hline AISTRA1 & 1160 & 26 & $871-937 \mathrm{AD}$ & $778-969 \mathrm{AD}$ \\
\hline AISTRA2 & 1035 & 28 & $988-1021 \mathrm{AD}$ & $906-1029 \mathrm{AD}$ \\
\hline
\end{tabular}

Fig 10. Radiocarbon dating of samples coming from the three studied Spanish sites

One can easily see that for the purposes of this article, the use of calibration results with $1 \sigma$ or $2 \sigma$ does not involve differences of interpretation. Therefore in the following we will always use the results obtained with the $1 \sigma$ distribution.

It must be pointed out that to correctly interpret these results, an early stratigraphical analysis was required to prove the existence of two constructive phases that includes the construction of a porch on the southern side. So, it has been possible to determine which walls could be really ascribed to the first half of the $12^{\text {th }}$ century.

On the other hand, the radiocarbonic dating, used isolated, provides a very wide chronological range, which 


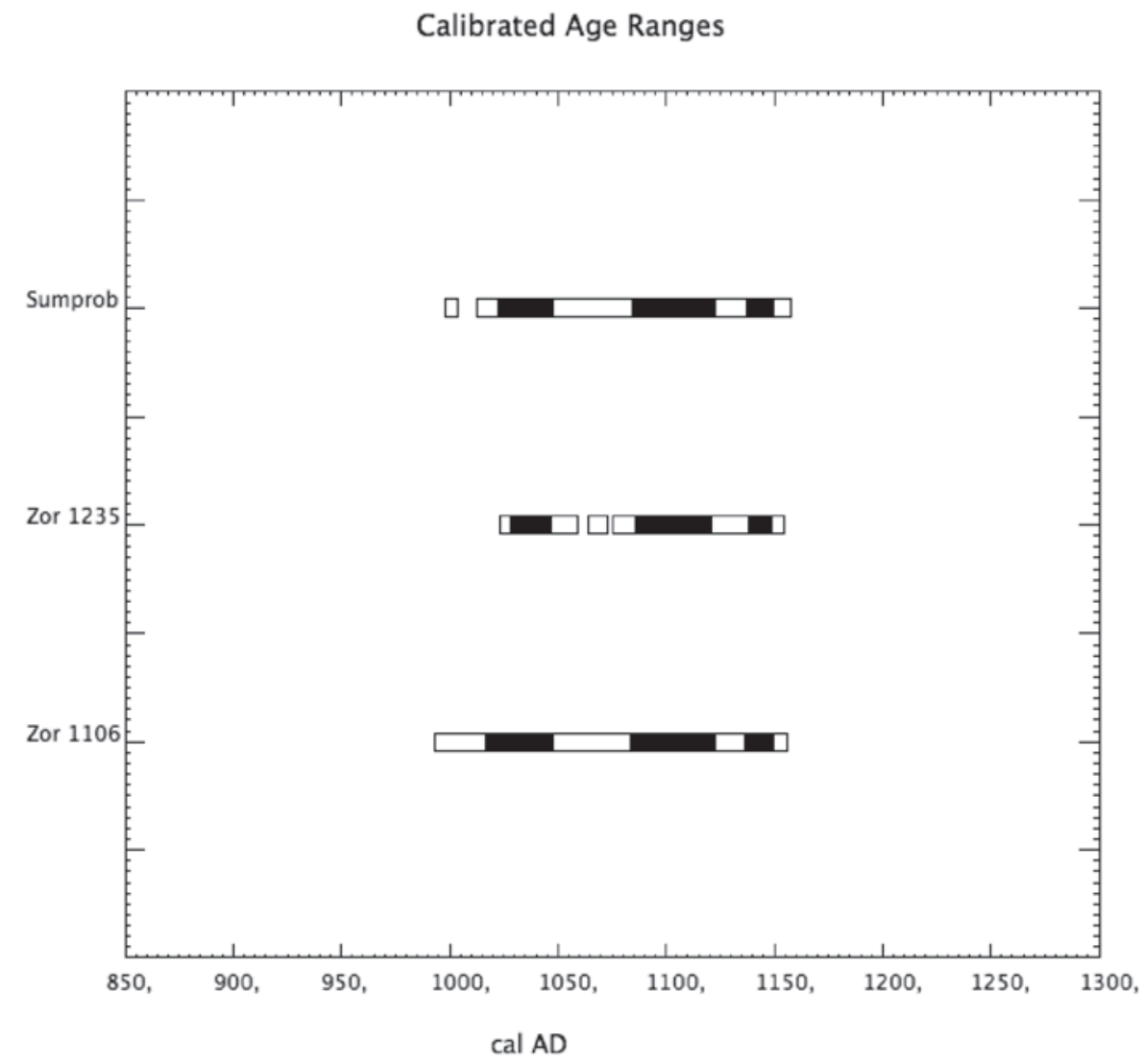

Fig. 11. Radiocarbon dating of sample coming from Zornoztegi. Zor 1235 Charcoal sample, Zor1106 mortar sample

leads us to conclude that the potentiality of this tool specially when we have a scarce number of measurements - multiplies when inserted in a wider archaeological analysis.

\subsection{San Julian and Santa Basilisa Church - Aistra}

Two samples belonging to the joints of the church of San Julian were sampled (AISTRA 1 and AISTRA 2). Results of radiocarbon dating are 871-937 AD $(1 \sigma)$ and 988-1021 AD $(1 \sigma)$ for AISTRA1 and AISTRA2, respectively (Fig. 9).

It must be pointed out that during the excavation a building has been identified (E8), made with wooden posts, in line with the main building. Thanks to ${ }^{14} \mathrm{C}$ dating of organic samples (charcoal in the context 144 and a seed in the context 149) from the fills of two postholes that form this construction, its manufacture was attributed to the $10^{\text {th }}$ century. Therefore, the dating of the first phase of the church is coherent with the dating of the E8 building and with the use of the cemetery associated to the funerary stele already mentioned, and we can ascribe its construction to the first decades of the $10^{\text {th }}$ century.
Otherwise, the second sample allow us to date the apse repair to between the last years of the $10^{\text {th }}$ century and the beginning of the $11^{\text {th }}$ century, previously ascribed to the 'Romanesque' period.

\subsection{Treviño castle}

Also in this study case, to avoid weather exposure contaminations, one sample from the core of a wall of this structure was sampled and analyzed (context $1502-\mathrm{lab}$ code CTV07).

The result of radiocarbon dating is 773-941 AD (1 $\sigma)$ (Fig. 9) confirming the chronology of the wall in the $10^{\text {th }}$ century.

So, the process of creating the Treviño castle has been interpreted as a hard lordship initiative. Taking that into account, since the $8^{\text {th }}$ century, the medieval settlement network was already well established throughout the area of Alava, the establishment of the castle of Treviño implies a real break in the network of settlements and also in the network of local authorities. The dating of the mortar of the walls has allowed us to understand the extent of this lordship action in this period. 


\section{CONCLUSION}

Radiocarbon dating of the mortar, according to the procedure presented here, opens new perspectives for the studies of historic architecture. In particular it can be used for cases in which it is not possible to make an analysis of a typological and formal nature or when we do not have other chronological indicators.

However, at least three very important aspects regarding the use of this technique in the archaeological study of historic architecture must be taken into account.

First of all, the availability of absolute dating with small errors cannot supplant the rigorous and systematic archaeological analysis of the building.

So radiocarbon dating of an archeological site makes no sense without first understanding the entire stratigraphy secuence (i.e. if the original contexts are primary or secondary deposition; if we are dating seeds, small pieces of wood or beams; if the stratigraphic sequence is consistent with the radiocarbon measurements); in the same way, even the dating of the mortar can not be a shortcut in the study of historic architecture.

In other words, the dating of the mortar should be a step in a broader cognitive process, which must necessarily start from an analysis of the complex stratigraphic analysis. For this reason, a date as that obtained at the castle of Treviño has not been interpreted simply as a witness for employment between the $8^{\text {th }}$ and $10^{\text {th }}$ centuries, but has been studied in light of a broader issue in relation to chronological consistency provided by other available indicators.

In short, this new instrumental resource cannot become a shortcut to avoid the full understanding of the construction history.

The second aspect to be taken into account is that it must be considered carefully when these techniques of analysis should be used, and their limitations and advantages. A single date for an entire site or building can only have a limited use or, at the very least, only be a guide. It is much more practical to have different dating within an overall strategy that integrates architecture dating to the determination of relative dating (the identification of the various phases of construction in a stratigraphic sequence) with the creation of different absolute dating (such as dating radiocarbon mortars), attributed to different walls of different phases. As has been emphasized in the literature (Mannoni 1984), it is essential to cross results obtained with different methodologies, with the aim of confirming the reliability of the instruments used but especially to reduce dating errors.
On the other hand, it should be emphasized that those who work in the historical age, unlike the case for prehistoric or geological periods, need to obtain very precise chronologies. Typical errors of radiocarbon dating performed at CIRCE laboratory are of 20-30 years for the radiocarbon age and we are trying to improve it (Terrasi 2008).

Moreover, they may increase following the calibration procedure. Indeed, the characteristics of the radiocarbon calibration curve indicate that in some historical periods, the date can be achieved with a smaller range over the calendar dating than during other periods. In fact, there are many problems involving the dating of finds of the 5$6^{\text {th }}, 8^{\text {th }}, 10^{\text {th }}$ and part of $11^{\text {th }}$ and $14^{\text {th }}$ centuries, while dates referring to the $7^{\text {th }}, 9^{\text {th }}, 13^{\text {th }}, 15^{\text {th }}$ and $17^{\text {th }}$ centuries are more accurate (Quirós Castillo 2009).

Finally, in view of the foregoing, it should be noted, as the third important aspect, that an archaeologist who uses archaeometrical analysis can not simply delegate to a specialized laboratory the solution to the problems posed by the architecture. As repeatedly pointed out by $\mathrm{T}$. Mannoni (Mannoni, 1990), the true interdisciplinary approach requires a permanent dialogue between the archaeologist who works in the field and researchers working in the laboratory, discussing and analysing critically the significance of the results.

Therefore, results from radiocarbon dating of mortar should be interpreted, taking into account the sampling strategy, the characterization of the mortars, the general analysis of the sequence of the employment site, and the processes of alteration of the mortars.

We conclude by observing how the fundamental qualitative step in the dating of historic architecture, not only depends on the discovery of new procedures, but, above all, on the ability to bring together interdisciplinary approaches in solving complex problems.

\section{ACKNOWLEDGMENT}

Research made in the framework of the investigation project funded by the Ministerio de Ciencia e Innovación with the title «La formación de los paisajes medievales en el Norte Peninsular» (HUM2009-07079) and the scientific collaboration agreement between the Universtiy of the Basque Country and the Dipartimento di Scienze Ambientali della Seconda Università di Napoli for the execution of archeometric studies related to the paleonutrition and the radiocarbon dating. Miren Goicoechea revised the text. 


\section{Bibliography}

Arbeiter A., Päffgen B., Karas U., 1994, «Die vor-und fruhromanische Kirche Santos Julian y Basilisa de Aistra bei Zalduondo (Álava)", Madrider Mitteilungen 35 , pp. 418-439

Azkarate Garai-Olaun A., 1988, Arqueología cristiana de la antigüedad tardía en Alava, Guipúzcoa y Vizcaya, Vitoria-Gasteiz

Azkarate Garai-Olaun A., García Camino I., 1996, Estelas e inscripciones medievales del País Vasco (siglos VI-X). I. País Vasco Occidental, Bilbao

Azkarate Garai-Olaun A., Sánchez Zufiaurre L., 2003, «Las iglesias prefeudales en Alava: Cronotipología y articulación espacial», Arqueología de la Arquitectura 2, pp. 25-36

Catón J. L., Guinea García E., 1987, «La conservación del patrimonio histórico en Alava : Ondare historikoaren zaingoa Araban», Vitoria-Gasteiz

Delibrias J., Labeyrie G., 1964, "Dating of old mortars by the carbon-14 method", Nature 201. pp. 742.

Folk R. L., Valastro S., 1976, «Successful technique for dating of lime mortar by carbon-14». Journal of Field Archaeology 3, pp. 203-208.

Fontaine J., 1978, El mózarabe, Madrid

Gallo N., Fieni L., Martini M., Sibilia E., 2000, «Building archeology, ${ }^{14} \mathrm{C}$ and thermoluminescence: two examples comparison", in Evin J., Oberlin C., Daugas J.P. \& Salles J.F. dir: Actes du 3éme congrès international Archéologie et $14 \mathrm{C}$, Paris, pp. $425-431$.

García Camino I., 2002, Arqueología y poblamiento en Bizkaia, siglos VI-XII. La configuración de la sociedad feudal, Bilbao.

García Retes E., 1987, «El camino de San Adrián (Guipúzcoa-Álava) en la ruta jacobea. Análisis documental y arqueológico», Estudios de Arqueología Alavesa 15, pp. 355-497

Hale, J., Heinemeier J., Lancaster L., Lindroos, A., Ringbom Å., 2003, «Dating Ancient Mortar». American Scientist, 91, pp. 130-137

Heinemeier, J., Jungner, H., Lindroos, A., Ringbom, A., von Konow, T. , Rud. N., 1997 "AMS 14C dating of lime mortar» Nuclear Instruments and Methods in Physics Research B 123, pp. 487-495.

Mannoni T., 1984, "Metodi di datazione dell'edilizia storica», Archeologia Medievale XI, pp. 396-403

Mannoni T., 1990, "Archeometria: archeografia o archeologia», Dialoghi di Archeologia serie III, anno 8, n. 2, pp. 77-81

Marzaioli F., Borriello G., Passariello I., Lubritto C., Cesare N. De, D’Onofrio A., Terrasi F., 2008, "Zinc reduction as an alternative method for Accelerator
Mass Spectrometry (AMS) radiocarbon dating: process optimization at CIRCE «(2008), Radiocarbon, 50 (1), pp. 139-149.

Marzaioli F., Lubritto C., Nonni, S., Passariello I., Capano M., Terrasi F., 2011, «Mortar Radiocarbon Dating: Preliminary Accuracy Evaluation of a Novel Methodology», Analytical Chemistry, 83 (6), pp. 2038-2045

Nawrocka D., Michniewicz J., Pawlyta J., Padzur A., 2005, «Application of radiocarbon method for dating of lime mortars", Geochronometria, 24 (2005): pp 109-115.

Quirós Castillo J. A. (dir.), 2010, Memoria final del proyecto arqueológico de Zornoztegi (Salvatierra-Agurain), Vitoria-Gasteiz

Quirós Castillo J. A., 2009, «Las dataciones radiocarbónicas de yacimientos de época histórica. Problemas y experiencias de análisis en contextos de época medieval», Munibe. Antropología y Arqueología 60, pp. 313-324

Quirós Castillo J. A., 2011, «L'eccezione che conferma la regola? Incastellamento nella valle dell'Ebro nel X secolo: il castello di Treviño", Archeologia Medievale XXXVIII, forthcoming

Reynolds A., Quirós Castillo J. A., 2007-2010, Despoblado de Aistra (Zalduondo), Arkeoikuska 06, pp. 94-100; 07, pp. 159-167; 08, pp. 209-211; 09, pp. 176-180

Sánchez Zufiaurre L., 2007, Técnicas constructivas medievales. Nuevos documentos para el estudio de la Alta Edad Media en Alava, Vitoria-Gasteiz

Sonninen \& Junger, 2001 «An improvement in preparation of mortar for radiocarbon dating» Radiocarbon 43 (2A), pp. 271-273

Stuiver, M., Polach, H.A., 1977 «Discussion: Reporting of 14C Data», Radiocarbon 19(3), pp 355-363.

Terrasi, F., De Cesare N., D’Onofrio A., Lubritto C., Marzaioli F., Passariello I., Rogalla D., Sabbarese C., Borriello G., Casa G., Palmieri A., 2008. «High precision ${ }^{14} \mathrm{C}$ AMS at CIRCE», Nuclear Instruments and Methods in Physcis Research, Sector B 266, pp. 2221-2224.

Utrero Agudo M. Á., 2006, «Iglesias tardoantiguas y altomedievales en la Península Ibérica. Análisis arqueológico y sistemas de abovedamiento», Anejos de Archivo Español de Arqueología Madrid

Van Strydonck M., Dupas M., Dauchot-Dehon M., Pachiaudi Ch. and Marechal J., 1986. "The influence of contaminating carbonate and the variations of ó $+{ }^{13} \mathrm{C}$ in mortar dating» Radiocarbon, 28 (2A), pp.702-710.

Recibido: 05 de agosto de 2011

Aceptado: 05 de octubre de 2011 